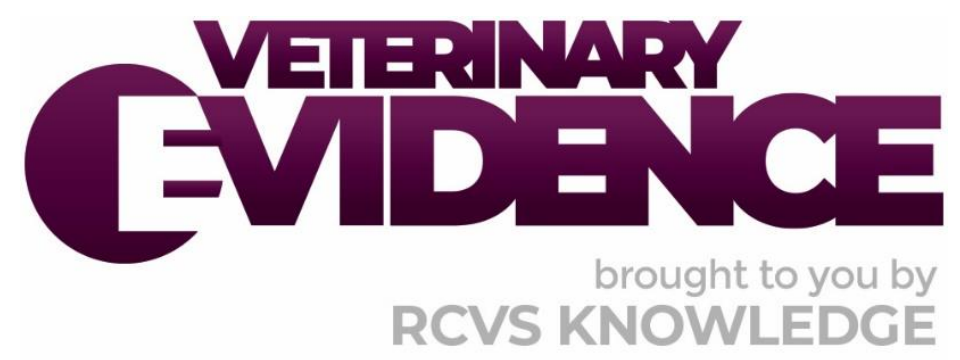

\title{
Can vaccinating sheep reduce the occurrence of caseous lymphadenitis?
}

\author{
A Knowledge Summary by \\ Vitória Souza de Oliveira Nascimento $\mathrm{BVM}^{1^{*}}$ \\ 187 Prof. Orlando Marques de Paiva, Sao Paulo, SP. 05508-010, Brazil
${ }^{*}$ Corresponding Author (vitoriasoliveira.n@gmail.com)
}

ISSN: 2396-9776

Published: 06 Jan 2020

in: Vol 5, Issue 1

DOI: 10.18849/VE.V5I1.247

Reviewed by: Paul Roger (BSc, BVetMed, MSc, CertWEL, DSHP, DipECAWBM, DipECSRHM, MRCVS) and Sohier M Syame (BSc, MSc, PhD)

Next Review Date: Jan 9th 2021 


\section{KNOWLEDGE SUMMARY}

\section{PICO question}

Is there a decrease of caseous lymphadenitis in vaccinated sheep compared to unvaccinated sheep?

\section{Clinical bottom line}

The evidence provided by the studies used is strong (all have been randomised controlled trials), supporting the hypothesis that sheep vaccinated against caseous lymphadenitis (CLA) are less likely to develop the disease when compared to unvaccinated sheep. Vaccination may be a useful tool in the prevention and control of clinical CLA following a risk assessment.

\section{Clinical Scenario}

Caseous lymphadenitis (CLA) is an important clinical disease found mainly in sheep which can have a high economic impact on sheep production. Knowing this, a sheep breeder asks the veterinarian during a regular visit to his farm how he could avoid this disease in his flock. He knows there are vaccines on the market, but wonders if they are really effective.

\section{The evidence}

In all the studies the animals were randomly allocated to experimental treatment groups, which provides a higher degree of confidence in the study (although most studies did not detail how this randomisation was done). From a total of 238 studies found, 218 were excluded. Of these, 169 were not related to the PICO question, 30 were not primary studies, three were excluded due to being written in a foreign language, 12 were related to other species and four were not available. Of the 20 studies selected, 10 had to be excluded because they were duplicates. In all the studies used it was found that animals vaccinated against CLA are less likely to acquire the disease when compared to unvaccinated animals. The vaccination for CLA is an effective measure for prophylaxis of the disease, since vaccinated animals were significantly less affected by the disease when compared to unvaccinated animals.

\section{Summary of the evidence}

\begin{tabular}{|r|l|}
\hline \multicolumn{2}{|l|}{ Sohier et al. (2018) } \\
\hline Population: & $\begin{array}{l}\text { From a group of } 50 \text { lambs negative for CLA (determined by enzyme- } \\
\text { linked immunosorbent assay (ELISA) test), a total of } 15 \text { Balady ewes, } \\
\text { approximately } 8-10 \text { months old, participated. }\end{array}$ \\
\hline Sample size: & 15 sheep (three per group) \\
\hline Intervention details: & $\begin{array}{l}15 \text { were allotted at random to five groups each group consisting of } \\
\text { three animals. Four groups were vaccinated by four different vaccine } \\
\text { formulas, and the fifth group was kept as an unvaccinated control }\end{array}$ \\
\hline
\end{tabular}




\begin{tabular}{|c|c|}
\hline & $\begin{array}{l}\text { group. } \\
\text { Group A (vaccine 1): Toxoid phospholipase D (PLD) - a preparation } \\
\text { of culture filtrate from isolated Corynebacterium pseudotuberculosis } \\
\text { biovar } 1.1 \mathrm{ml} \text { of the filtrate was mixed with } 1 \mathrm{ml} \text { of oil adjuvant } \\
\text { vaccine, dose ( } 2 \text { ml) contained } 23 \mu \mathrm{g} \text { PLD, and the vaccine was } \\
\text { inoculated subcutaneously, in the middle third of the neck. } \\
\text { Group B (vaccine 2): PLD - bacterin composed of formalin-killed C. } \\
\text { pseudotuberculosis whole cells mixed with the toxoid PLD vaccine. } \\
\text { 164 killed bacteria cells and } 23 \mu \mathrm{PLD} / 1 \text { ml, and the dose ( } 2 \text { ml) was } \\
\text { inoculated subcutaneously, in the middle third of the neck. } \\
\text { Group C (vaccine } 3 \text { ): Toxoid PLD with covaccine } 8-\text { covaccine } 8 \text { is an } \\
\text { imported vaccine formulated from a mixture of clostridial toxins, } \\
\text { obtained from Schering Plough Animal Health. The mixture } \\
\text { contained } 23 \mu \text { PLD in } 40 \text { ml of covaccine } 8,2 \text { ml inoculated } \\
\text { subcutaneously, in the middle third of the neck. } \\
\text { Group D (vaccine } 4 \text { ): Toxoid PLD vaccine combined with the poly- } \\
\text { valent clostridial vaccine }- \text { Clostridium perfringens, Clostridium } \\
\text { tetani, Clostridium septicum, Clostridium chauvoei, and Clostridium } \\
\text { novyi. } 40 \text { ml of polyvalent clostridial vaccine mixed with } 6 \text { g } \\
\text { lyophilised powder formulated culture filtrate PLD. The polyvalent is } \\
\text { a local vaccine prepared by Veterinary Serum and Vaccine Research } \\
\text { Institute (Abbasia, Cairo, Egypt). The } 2 \text { ml dose of the vaccine was } \\
\text { inoculated subcutaneously in the middle third of the neck. } \\
\text { Group E (control): Unvaccinated animals. } \\
\text { Statistical analysis was done using model Generalised Linear Model } \\
\text { (GLM) of Statistical Analysis System (SAS) and software version } 6.12 \text {. } \\
\text { first vaccination. } \\
\text { After } 3 \text { weeks of the last vaccination, all five groups were challenged } \\
\text { with virulent biovar } 1 \text { sheep origin isolate with } 2 \text { ml suspension } \\
\text { containing } 4 \times 106 \text { colony forming unit (CFU), } 1 \text { ml vaccine was } \\
\text { inoculated subcutaneously in the middle third of the each side of the } \\
\text { neck. The non-specific cellular immune response represented by } \\
\text { stimulated macrophages was measured at } 2 \text { weeks after the } \\
\text { challenge while the specific excited lymphocytes response was } \\
\text { assessed at } 4 \text { weeks. }\end{array}$ \\
\hline Study design: & Randomised controlled trial \\
\hline Outcome studied: & $\begin{array}{l}\text { Perform a comparative innate and acquired immune response } \\
\text { assessment of four different vaccine formulas to evoke protection } \\
\text { against induced CLA in sheep. } \\
\text { The specific immune response was evaluated through lymphocyte } \\
\text { proliferation assay using ELISA BrdU kit, while the non-specific }\end{array}$ \\
\hline
\end{tabular}




\begin{tabular}{|r|l|}
\hline Main findings: & $\begin{array}{l}\text { response was estimated by superoxide anion production and } \\
\text { lysozyme activity assays. }\end{array}$ \\
\hline (relevant to PICO question): & $\begin{array}{l}\text { The study indicated that the toxoid PLD vaccine alone (group A) was } \\
\text { most efficient and provided innate and acquired immune response } \\
\text { in animals against CLA. The vaccine evoked the highest stimulation } \\
\text { index, which expressed specific lymphocyte proliferation response } \\
\text { by a big margin compared to the other combined vaccines. }\end{array}$ \\
\hline Limitations: & $\begin{array}{l}\text { It does not inform whether the control animals were vaccinated with } \\
\text { placebo and does not report the method of randomisation. }\end{array}$ \\
\hline
\end{tabular}

Eshra et al. (2018)

\begin{tabular}{|c|c|}
\hline Population: & $\begin{array}{l}15 \text { native sheep, of about } 6-8 \text { months of age were apparently } \\
\text { healthy with no history of CLA. They were kept under clinical } \\
\text { observation for } 1 \text { month. All sheep selected for the experiment had } \\
\text { negative ELISA test. }\end{array}$ \\
\hline Sample size: & 15 sheep (five per group) \\
\hline Intervention details: & $\begin{array}{l}\text { Sheep were divided into three groups (five animals per group) as } \\
\text { follows: } \\
\text { Group I: Vaccinated with } 0.1 \mathrm{ml} \text { of Bacillus Calmette-Guérin (BCG) } \\
\text { (supplied by Veterinary Serum and Vaccine Research Institute, used } \\
\text { for vaccination of sheep dose of } 0.1 \mathrm{ml} \text { ), simultaneously injected } \\
\text { intradermally with the first dose of } 2.0 \mathrm{ml} \text { of the prepared CLA } \\
\text { vaccine injected subcutaneously, then booster dose injected } 21 \text { days } \\
\text { apart. } \\
\text { Group II: Vaccinated with } 2.0 \mathrm{ml} \text { of prepared CLA vaccine then } \\
\text { booster dose injected } 21 \text { days apart (injected subcutaneously). } \\
\text { Group III: Control group. }\end{array}$ \\
\hline Study design: & Randomised controlled trial. \\
\hline Outcome studied: & $\begin{array}{l}\text { The study was directed to develop oil adjuvant vaccine from killed } \\
\text { local isolated C. pseudotuberculosis field strain and evaluation of its } \\
\text { humoral and cellular immunity response in sheep of the prepared } \\
\text { vaccine only and combined with BCG. } \\
\text { They were evaluated as cellular and humoral immune responses, } \\
\text { through evaluation by phagocytic activity and index, and differential } \\
\text { count of leukocytes and ELISA, respectively. }\end{array}$ \\
\hline $\begin{array}{l}\text { Main findings: } \\
\text { (relevant to PICO question): }\end{array}$ & $\begin{array}{l}\text { Proved (in groups I and II) to induce cellular and humoral immunity } \\
\text { and could be used for prevention and control of CLA in sheep. } \\
\text { Group I: Immune response mediated by phagocytic activity and } \\
\text { phagocytic index between } 0 \text { and } 44 \text { days average of } 62.25 \% \text {; } \\
\text { Group II: Immune response mediated by phagocytic activity and } \\
\text { phagocytic index between } 0 \text { and } 44 \text { days average of } 61 \% \text {; }\end{array}$ \\
\hline
\end{tabular}




\begin{tabular}{|c|l|}
\hline & $\begin{array}{l}\text { Group III: Immune response mediated by phagocytic activity and } \\
\text { phagocytic index between } 0 \text { and } 44 \text { days average of } 55.5 \% .\end{array}$ \\
\begin{tabular}{l} 
Average humoral immune response (by optical density of colored \\
reaction): \\
Group I: day 0: $0.136 ;$ day $21: 0.397 ;$ day $44: 0.394 ;$ day $60: 0.371 ;$ \\
Group II: day 0: $0.149 ;$ day $21: 0.372 ;$ day $44: 0.382 ;$ day $60: 0.332 ;$ \\
Group II: day 0: $0.143 ;$ day $21: 0.133 ;$ day $44: 0.145 ;$ day $60: 0.145$. \\
\hline Limitations:
\end{tabular} & $\begin{array}{l}\text { Does not explain how randomisation was performed and whether } \\
\text { the control animals were vaccinated with placebo. }\end{array}$ \\
\hline
\end{tabular}

\begin{tabular}{|c|c|}
\hline \multicolumn{2}{|l|}{ Ghani et al. (2016) } \\
\hline Population: & $\begin{array}{l}\text { Male lambs (Awassi), ages ranged } 5-7 \text { months old. The animals were } \\
\text { bred in the Veterinary Medicine University of Baghdad. } \\
\text { All lambs were treated by ivermectin } 200 \mu \mathrm{g} \text { per kg of body weight } \\
\text { subcutaneous at the rate of } 1 \mathrm{ml} \text { per } 50 \mathrm{~kg} \text { as anthelminthic } \\
\text { treatment for internal and external parasites before starting the } \\
\text { experiment. } \\
\text { Lambs divided into three groups each group consisted of five lambs. }\end{array}$ \\
\hline Sample size: & 15 lambs (five per group) \\
\hline Intervention details: & $\begin{array}{l}\text { The animals were separated into three groups. There is no } \\
\text { information on how this allocation was made. } \\
\text { Group I: five lambs as negative control. } \\
\text { Group II: five lambs vaccinated (a commercial vaccine prepared by } \\
\text { Colorado Serum Company (U.S.A.), detoxified and purified the whole } \\
\text { culture of } C \text {. pseudotuberculosis contains thimerosal as preservative } \\
\text { used in healthy sheep as a killed bacterin-toxoid vaccine. The } \\
\text { vaccine injected subcutaneously in a dose of } 2 \mathrm{ml} \text { in axillary space } \\
\text { and repeated in four weeks in opposite axillary space). } \\
\text { Group III: five lambs as positive control. }\end{array}$ \\
\hline Study design: & Randomised controlled trial \\
\hline Outcome studied: & $\begin{array}{l}\text { To know the efficacy of commercial vaccine (Case-Bac Vaccine) by } \\
\text { immunisation trials against the CLA disease in sheep and study } \\
\text { cellular and humoral immunity. } \\
\text { Humoral and cell mediated immune response was detected during } \\
\text { the period of experiments, the temperature, pulse rate and }\end{array}$ \\
\hline
\end{tabular}




\begin{tabular}{|c|l|}
\hline Main findings: & $\begin{array}{l}\text { respiration rate were determined weekly. } \\
\text { Cellular immune responses of the vaccinated and control groups } \\
\text { were evaluated by delayed type of hypersensitivity (DTH) skin test. }\end{array}$ \\
\hline (relevant to PICO question): & $\begin{array}{l}\text { The vaccine appeared to offer an excellent protection against the } \\
\text { development of CLA in sheep and the vaccine could play an } \\
\text { important role in the control of the disease in infected sheep flocks. } \\
\text { Antibody titer two weeks after first vaccination dose (mean optical } \\
\text { density values): } \\
\text { Group I: } 0.096 \pm 0.013 \\
\text { Limitations: }\end{array}$ \\
& $\begin{array}{l}\text { Group II: } 0.426 \pm 0.26-\text { The maximum titre was reached in the } \\
\text { eighth week after vaccination (1.984 } \pm 0.776) \text { and then the antibody } \\
\text { titers begun to decrease to } 0.95 \pm 0.446\end{array}$ \\
Group III: $0.093 \pm 0.01$
\end{tabular}

\begin{tabular}{|c|c|}
\hline Izgür et al. (2010) & \\
\hline Population: & Mixed Akkaraman lambs, approximately 6 months old \\
\hline Sample size: & 140 lambs \\
\hline Intervention details: & $\begin{array}{l}140 \text { lambs were selected, of these } 28 \text { were positive for } C \text {. } \\
\text { tuberculosis and were excluded from the studies. Of the } 112 \text { lambs } \\
\text { negative for antibodies against the exotoxin of } C \text {. pseudotuberculosis } \\
\text { as determined by the haemolysis inhibition test (HIT), } 90 \text { animals } \\
\text { were randomly chosen. } 90 \text { lambs were allotted at random to three } \\
\text { groups ( } 30 \text { lambs in each group): } \\
\text { Group I: was vaccinated with a vaccine prepared from } C \text {. } \\
\text { pseudotuberculosis PI } 18 \text { strain. The vaccine injected subcutaneously } \\
\text { in a dose of } 0.5 \mathrm{ml} \text { (two doses). } \\
\text { Group II: with a vaccine prepared from } C \text {. pseudotuberculosis Cy } 5 \\
\text { strain. The vaccine injected subcutaneously in a dose of } 0.5 \mathrm{ml} \text { (two } \\
\text { doses). } \\
\text { Group III: was used as a control and was subcutaneously injected } \\
\text { with } 2.0 \mathrm{ml} \text { phosphate buffer solution (PBS). }\end{array}$ \\
\hline Study design: & Randomised controlled trial \\
\hline Outcome studied: & $\begin{array}{l}\text { Identify major antigens of } C \text {. pseudotuberculosis isolated from } \\
\text { different sheep flocks in Turkey and to evaluate the efficacy of the } \\
\text { vaccine formulated as bacterin }+ \text { toxoid }+ \text { Freund's complete } \\
\text { adjuvant (FCA) (groups I and II) against bacterial challenge in lambs. } \\
\text { Cellular immune responses of the vaccinated and control groups }\end{array}$ \\
\hline
\end{tabular}




\begin{tabular}{|c|l|}
\hline Main findings: & were evaluated by DTH skin test. \\
\hline (relevant to PICO question): & $\begin{array}{l}\text { When a local C. pseudotuberculosis (PI 18) strain was used and } \\
\text { formulated as per ml of the vaccine, 1.5 } \times 10^{8} \text { colony-forming unit } \\
\text { (CFU) of C. pseudotuberculosis bacterin }+ \text { toxoid }+1 / 2 \text { FCA of the } \\
\text { toxoid, obtained a high percentage of protection regarding the } \\
\text { potential of this vaccine to control CLA in sheep, as seen in groups I } \\
\text { and II. }\end{array}$ \\
\hline Limitations: & $\begin{array}{l}\text { Method of randomisation not stated and not all animals present at } \\
\text { the beginning of the study were allocated to the groups. }\end{array}$ \\
\hline
\end{tabular}

\begin{tabular}{|c|c|}
\hline \multicolumn{2}{|l|}{ Stanford et al. (1998) } \\
\hline Population: & $\begin{array}{l}\text { 1992: } 620 \text { lambs (Rambouillet, Suffolk, Finn, Dorset and Romanov) } \\
\text { 1993: } 453 \text { lambs (Rambouillet, Suffolk, Dorset, Romanov and Finn) } \\
\text { 1994-1996: nine flocks containing } 2176 \text { ewes and lambs (not } \\
\text { informed breeds) } \\
\text { Serum samples were collected prior to vaccination from all animals } \\
\text { (mature stock and lambs). The microagglutination test was used to } \\
\text { distinguish among vaccinated and unvaccinated animals. }\end{array}$ \\
\hline Sample size: & 3249 lambs \\
\hline Intervention details: & $\begin{array}{l}\text { In 1992, lambs were assigned to one of } 3 \text { groups: } \\
\text { Group I: control (no vaccine); } \\
\text { Group II: whole cells (WC) + 2-acetamido-2- } \\
\text { deoxy-3-O-D-2-propionyl-L-alanyl- } \\
\text { D-isoglutamine-D-glucopyranose-snglyceryl- } \\
\text { dipalmitoyl) (MDP-GDP), administered intramuscularly; } \\
\text { Group III: Glanvac, administered subcutaneously; } \\
\text { In 1993, lambs were randomly assigned to one of } 3 \text { groups: } \\
\text { Group I: control (no vaccine); } \\
\text { Group II:WC+MDP-GDP, administered intramuscularly; } \\
\text { Group III: Case-Vac, administered subcutaneously; } \\
\text { 1994-1996, ewes and lambs were assigned to } 2 \text { groups: } \\
\text { Group I: control (saline), administered subcutaneously; } \\
\text { Group II: WC+MDP-GDP, administered intramuscularly; } \\
\text { It does not report the number of animals allocated to each group } \\
\text { and the dose of each injection. }\end{array}$ \\
\hline Study design: & Randomised controlled trial \\
\hline Outcome studied: & $\begin{array}{l}\text { To assess the efficacy and impact of vaccination with two } \\
\text { commercial (Glanvac-6 and Case-Vac) and one experimental } \\
\text { (WC+MDP-GDP). } \\
\text { Identify major antigens of } C \text {. pseudotuberculosis isolated from } \\
\text { different sheep flocks in Turkey and to evaluate the efficacy of the } \\
\text { vaccine formulated as bacterin }+ \text { toxoid }+ \text { Freund's complete } \\
\text { adjuvant (FCA) against bacterial challenge in lambs. Cellular immune } \\
\text { responses of the vaccinated and control groups were evaluated by }\end{array}$ \\
\hline
\end{tabular}




\begin{tabular}{|r|l|}
\hline Main findings: & DTH. \\
\hline (relevant to PICO question): & $\begin{array}{l}\text { Serum samples were collected prior to vaccination from all animals } \\
\text { (mature stock and lambs) and 1, 3,6,9, and } 12 \text { months after } \\
\text { vaccination. }\end{array}$ \\
\hline $\begin{array}{l}\text { When a local C. pseudotuberculosis (PI 18) strain was used and } \\
\text { formulated as per ml of the vaccine, 1.5x10 CFU of C. } \\
\text { pseudotuberculosis bacterin + toxoid }+1 / 2 \text { FCA of the toxoid, we } \\
\text { obtained protection regarding the potential of this vaccine to control } \\
\text { of CLA in sheep. } \\
\text { In all industry flocks, antibody titres for both lambs and mature } \\
\text { stock were significantly higher than those of controls immediately } \\
\text { prior to, and } 1 \text { month after, the booster vaccination. }\end{array}$ \\
\hline Limitations: & $\begin{array}{l}\text { It does not report the doses of each vaccine type and how } \\
\text { randomisation was performed. }\end{array}$ \\
\hline
\end{tabular}

Panton et al. (1995)

\begin{tabular}{|c|c|}
\hline Population: & 5 month old lambs \\
\hline Sample size: & 450 lambs \\
\hline Intervention details: & 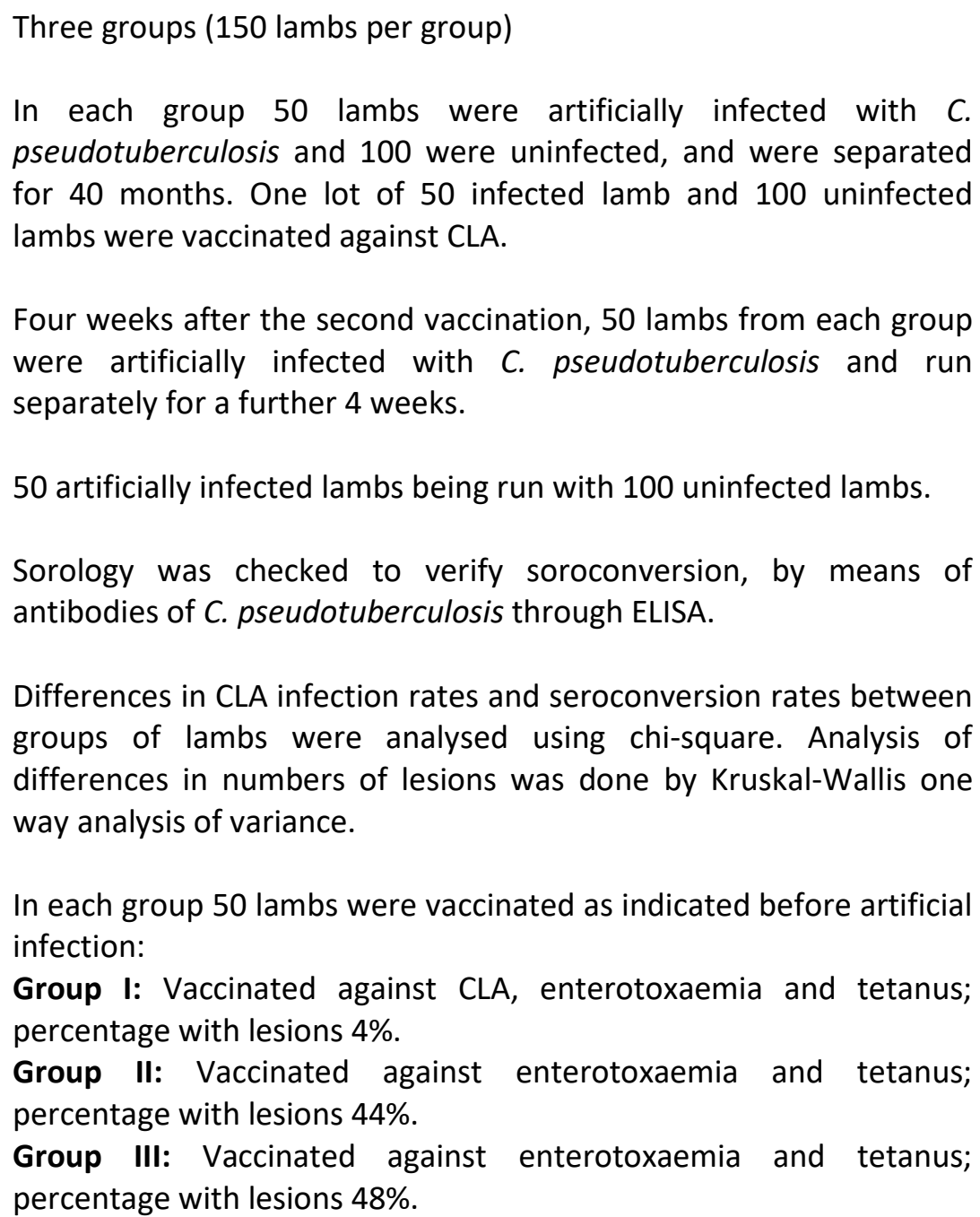 \\
\hline
\end{tabular}




\begin{tabular}{|c|c|}
\hline & $\begin{array}{l}\text { In each group } 100 \text { lambs were run with } 50 \text { artificially infected lambs: } \\
\text { Group I: Vaccinated against CLA, enterotoxaemia and tetanus; } \\
\text { percentage with lesions } 2 \% \text {. } \\
\text { Group II: Vaccinated against CLA, enterotoxaemia and tetanus; } \\
\text { percentage with lesions } 20 \% \text {. } \\
\text { Group III: Vaccinated against enterotoxaemia and tetanus; } \\
\text { percentage with lesions } 76 \% \text {. }\end{array}$ \\
\hline Study design: & Randomised controlled trial \\
\hline Outcome studied: & $\begin{array}{l}\text { Investigate the relative importance of different models of CLA and } \\
\text { dissemination under conditions found incompatible within sheep } \\
\text { flocks. } \\
\text { Evaluated percentage of lambs with lesion CLA and number of } \\
\text { lesions, besides the presence of antibodies to C. pseudotuberculosis } \\
\text { exotoxin and cell wall. }\end{array}$ \\
\hline $\begin{array}{l}\text { Main findings: } \\
\text { (relevant to PICO question): }\end{array}$ & $\begin{array}{l}\text { Lambs vaccinated against CLA and naturally exposed to infection had } \\
74 \% \text { lower infection rate than unvaccinated sheep. } \\
\text { Lambs vaccinated against CLA had a } 97 \% \text { lower infection rate } \\
\text { (groups I and II). } \\
\text { Unvaccinated lambs had a } 76 \% \text { infection rate (groups III). } \\
\text { Vaccinated lambs infected with CLA have } 96 \% \text { fewer lung abscesses } \\
\text { compared with unvaccinated infected lambs and therefore less likely } \\
\text { to spread this disease to other lambs. }\end{array}$ \\
\hline Limitations: & $\begin{array}{l}\text { Does not inform if vaccines have been administered intramuscularly } \\
\text { or subcutaneously and how randomisation was performed. }\end{array}$ \\
\hline
\end{tabular}

Menzies et al. (1991)

\begin{tabular}{|r|l|}
\hline Population: & $\begin{array}{l}\text { Female lambs and kids from one sheep flock. (The study was } \\
\text { conducted parallel with goats and sheep. This Knowledge Summary } \\
\text { only considers the results of the sheep). }\end{array}$ \\
\hline Sample size: & 88 lambs (44 controls and 44 vaccinates) \\
\hline Intervention details: & $\begin{array}{l}\text { Group I: Vaccinated; } 44 \text { lambs } \\
\text { Groups II: Unvaccinated; } 44 \text { lambs }\end{array}$ \\
$\begin{aligned} \text { Females and offspring were allocated to groups. } \\
\text { The animals were vaccinated between } 2.5 \text { and } 3.5 \text { months of age, } \\
\text { the vaccination was repeated } 1 \text { month later and again } 11 \text { months } \\
\text { later. } \\
\text { Each dose of vaccine consisted of } 0.25 \mathrm{ml} \text { sterile saline, } 0.25 \mathrm{ml} \\
\text { mineral oil with } 3 \% \text { Arlacel A and either } 5.0 \text { mg dried whole } C . \\
\text { pseudotuberculosis cells (initial vaccination and } 1 \text { month booster) or } \\
1.0 \text { mg dried whole cells (12 month booster). The total volume for }\end{aligned}$ \\
\hline
\end{tabular}




\begin{tabular}{|c|c|}
\hline & $\begin{array}{l}\text { each injection was } 0.5 \mathrm{ml} \text {. } \\
\text { The serums were analysed by microagglutination assay for the } \\
\text { detection of antibodies to } C \text {. pseudotuberculosis. Animals were } \\
\text { monitored for the development of abscesses by the technician at } \\
\text { each serum collection visit and by routine observation by the farm } \\
\text { managers. } \\
\text { The level of significance of the microagglutination was determined } \\
\text { by the Student's t-test and was used the logrank test for difference } \\
\text { in proportions of new cases in each group over time. }\end{array}$ \\
\hline Study design: & Randomised controlled trial \\
\hline Outcome studied: & $\begin{array}{l}\text { The purpose of this field trial was to evaluate the efficacy of a killed } \\
\text { whole cell vaccine in preventing CLA in sheep by induction of } \\
\text { infection. }\end{array}$ \\
\hline $\begin{array}{l}\text { Main findings: } \\
\text { (relevant to PICO question): }\end{array}$ & $\begin{array}{l}\text { There was a significant difference in the proportion of vaccinated } \\
\text { sheep that developed CLA compared to the control sheep at each } \\
\text { time interval except less than } 6 \text { months post initial vaccination. } \\
\text { The vaccine appeared to produce a persistently elevated serum } \\
\text { antibody titre to } C \text {. pseudotuberculosis as measured by the } \\
\text { microagglutination assay. There was also a statistically significant } \\
\text { degree of protection in sheep against the development of clinical } \\
\text { CLA. } \\
\text { The vaccine could have a significant role in the control of CLA in } \\
\text { infected sheep. }\end{array}$ \\
\hline Limitations: & $\begin{array}{l}\text { It does not detail the populations or how the randomisation was } \\
\text { performed and does not inform if vaccines have been administered } \\
\text { intramuscularly or subcutaneously. }\end{array}$ \\
\hline
\end{tabular}

Eggleton et al. (1991)

\begin{tabular}{|r|l|}
\hline Population: & Romney Marsh lambs, 3-4 months of age \\
\hline Sample size: & 133 lambs \\
\hline Intervention details: & $\begin{array}{l}\text { Lambs were vaccinated with two doses of vaccine }(2.0 \mathrm{ml} \text { - interval } \\
\text { of } 28 \text { days). } \\
\text { Group 1 - immunised with monocomponent vaccine (vaccine } \\
\text { prepared from C. pseudotuberculosis); 38 lambs; administered } \\
\text { subcutaneously. } \\
\text { Group 2-immunised with the combined vaccine (vaccine prepared } \\
\text { from C. pseudotuberculosis and Clostridium perfrigens D, Clostridium } \\
\text { novyi B, Clostridium tetani, Clostridium septicum and Clostridium } \\
\text { chavouei); 38 lambs; administered subcutaneously. }\end{array}$ \\
\hline
\end{tabular}




\begin{tabular}{|c|c|}
\hline & $\begin{array}{l}\text { Group } 3 \text { - immunised with the combined vaccine (vaccine prepared } \\
\text { from C. pseudotuberculosis, Clostridium perfrigens } D \text {, Clostridium } \\
\text { novyi B, Clostridium tetani, Clostridium septicum and Clostridium } \\
\text { chavouei and selenium); } 24 \text { lambs; administered subcutaneously. } \\
\text { Group } 4 \text { - control; } 33 \text { lambs } \\
\text { Serology and necropsy were performed (to verify lesions caused by } \\
\text { CLA). }\end{array}$ \\
\hline Study design: & Randomised controlled trial \\
\hline Outcome studied: & $\begin{array}{l}\text { Compare the protective efficacy of monocomponent and combined } \\
\text { clostridial-corynebacterial vaccines. }\end{array}$ \\
\hline $\begin{array}{l}\text { Main findings: } \\
\text { (relevant to PICO question): }\end{array}$ & $\begin{array}{l}\text { Regarding necropsy, } 12 / 145 \text { animals were omitted after accidental } \\
\text { death. } 17 / 33 \text { animals belonging to the control group had lesions, as } \\
\text { well as } 4 / 38 \text { animals from group } 1,3 / 38 \text { animals from group } 2,2 / 24 \\
\text { from group } 3 \text {. } \\
\text { All three vaccines afforded an equal and high level of protection. } \\
91 \% \text { ( } 91 / 100) \text { of vaccinated sheep exhibiting no lesions of caseous } \\
\text { lymphadenitis CLA, compared with } 51.5 \% \text { (17/33) affected sheep in } \\
\text { the control group). } \\
\text { Average lesion counts were } 1.2 \text { per affected vaccinated sheep and } \\
4.5 \text { per affected control sheep. } \\
\text { Antitoxin responses to the clostridial toxoids incorporated in the } \\
\text { combined vaccines were not affected by inclusion of the C. } \\
\text { pseudotuberculosis toxoid or the sodium selenate. } \\
\text { The results indicate the overall efficacy of vaccines in controlling CLA } \\
\text { infection. }\end{array}$ \\
\hline Limitations: & $\begin{array}{l}\text { It does not detail the populations or how the randomisation was } \\
\text { performed and does not report whether placebo was used in the } \\
\text { control group }\end{array}$ \\
\hline
\end{tabular}

\begin{tabular}{|r|l|}
\hline Eggleton et al. (1991) \\
\hline Population: & $\begin{array}{l}\text { Romney Marsh lambs, } 6 \text { months of age (maintained at the CSL Field } \\
\text { Station (Woodend, Victoria, Australia). }\end{array}$ \\
\hline Sample size: & 84 (16 animals were omitted from the study because they died). \\
\hline Intervention details: & $\begin{array}{l}\text { Each group started with } 20 \text { lambs, but } 16 \text { animals were omitted } \\
\text { from the study because they died. } \\
\text { Vaccine was prepared from C. pseudotuberculosis toxoid combined } \\
\text { with aluminum hydroxide as adjuvant. } \\
\text { Each sheep received two doses of } 2 \text { ml of the appropriate vaccine } \\
\text { administered subcutaneously in the neck. The interval between } \\
\text { doses was 34 days. }\end{array}$ \\
\hline
\end{tabular}




\begin{tabular}{|c|c|}
\hline & $\begin{array}{l}\text { Control group (unvaccinated): } 17 \text { lambs of which } 15 \text { were affected } \\
\text { by CLA. } \\
\text { Group } 1 \text { (vaccine high toxine-toxoid: cell-free toxoid): } 14 \text { lambs of } \\
\text { which three were affected by CLA. } \\
\text { Group } 2 \text { (vaccine high toxine-toxoid-cells: toxoid with formalin- } \\
\text { killed cells): } 15 \text { lambs of which four were affected by CLA. } \\
\text { Group } 3 \text { (vaccine low toxine-toxoid: cell-free toxoid): } 18 \text { lambs of } \\
\text { which four were affected by CLA. } \\
\text { Group } 4 \text { (vaccine low toxine-toxoid-cells: toxoid with formalin- } \\
\text { killed cells): } 20 \text { lambs of which five were affected by CLA. }\end{array}$ \\
\hline Study design: & Randomised controlled trial \\
\hline Outcome studied: & $\begin{array}{l}\text { Verify if there is adequate protection in sheep vaccinated against } \\
\text { CLA. }\end{array}$ \\
\hline $\begin{array}{l}\text { Main findings: } \\
\text { (relevant to PICO question): }\end{array}$ & $\begin{array}{l}\text { The primary responses and peak secondary responses to the four } \\
\text { vaccines did not differ widely, and the subsequent decline of } \\
\text { antitoxin titres with time was identical for vaccine groups } 3 \text { and } 4 \text {, } \\
\text { with only minor exception in the fourth vaccine group. } \\
\text { Necropsy results: } \\
\text { Control group (unvaccinated): } 15 \text { (15/17) were affected. Ten sheep } \\
\text { had lesions in both lung and carcase, } 4 \text { had lung lesions only and one } \\
\text { had carcase lesions only. The average number of lesions per affected } \\
\text { sheep was } 27.1 \\
\text { Group } 1-3(3 / 14) \text { were affected the lesions being found in the } \\
\text { lungs only. The average number of lesions per affected sheep was } \\
2.0 \text {. } \\
\text { Group } 2-4(4 / 15) \text { were affected, all with carcase lesions only. The } \\
\text { average number of lesions per affected sheep was } 1.5 \\
\text { Group } 3-4(4 / 18) \text { were affected, } 3 \text { with lung lesions only and one } \\
\text { with kidney lesions only. The average number of lesions per affected } \\
\text { sheep was } 3.0 \text {. } \\
\text { Group } 4-5(5 / 20) \text { were affected, one with carcase and lung lesions, } \\
2 \text { with carcase lesions only and } 2 \text { with lung lesions only. The average } \\
\text { number of lesions per affected sheep was } 3.6 \text {. } \\
\text { The protective potency of the vaccines was not improve by the } \\
\text { inclusion of cells of } C \text {. pseudotuberculosis. }\end{array}$ \\
\hline Limitations: & $\begin{array}{l}\text { It does not detail how statistical analysis of the data was performed } \\
\text { and population and method of randomisation is not stated. }\end{array}$ \\
\hline
\end{tabular}

LeaMaster et al. (1987)

\begin{tabular}{|r|l|}
\hline Population: & Romney Marsh lambs, 6 months of age \\
\hline Sample size: & 63 mixed-breed, white-faced lambs \\
\hline
\end{tabular}




\begin{tabular}{|c|c|}
\hline Intervention details: & $\begin{array}{l}\text { Each group started with } 21 \text { lambs. } \\
\text { Group 1: was vaccinated of using } 2 \mathrm{ml} \mathrm{a} C \text {. pseudotuberculosis } \\
\text { bacterin given subcutaneously in the right axillary region at the } \\
\text { beginning of the study. } \\
\text { Group 2: was vaccinated twice, being the first vaccination done on } \\
\text { the same day as the group } 1 \text { and the second } 4 \text { weeks after } \\
\text { Group } 3 \text { (unvaccinated): control group was given saline solution ( } 2 \\
\text { ml subcutaneously). } \\
\text { Blood samples were collected immediately prior to the first } \\
\text { vaccination and then weekly until week } 11 \text {. From week } 11 \text { to the end } \\
\text { of the study (week } 25 \text { ), samples were collected approximately every } \\
2 \text { weeks. } \\
\text { ELISA was used to detect antibodies against } C \text {. pseudotuberculosis. } \\
13 \text { weeks after inoculation all lambs were necropsied without } \\
\text { knowledge of treatment groups to verify the presence of abscesses. }\end{array}$ \\
\hline Study design: & Randomised controlled trial \\
\hline Outcome studied: & $\begin{array}{l}\text { To evaluate efficacy of a } C \text {. pseudotuberculosis bacterin to protect } \\
\text { sheep immunologically against the development of CLA, through } \\
\text { controlled challenge exposure experiments. }\end{array}$ \\
\hline $\begin{array}{l}\text { Main findings: } \\
\text { (relevant to PICO question): }\end{array}$ & $\begin{array}{l}\text { The number of internal lesions per lamb was four for group } 1 \text {, two } \\
\text { for group } 2 \text {, and } 14 \text { group for } 3 \text {. } \\
\text { The average number of abscesses per lamb was seven for group } 1 \text {, } \\
\text { four for group } 2 \text { and } 32 \text { for group } 3 \text {. } \\
\text { The results of the study indicated that the vaccine provided } \\
\text { immunological protection of lamb against challenge exposure of } C \text {. } \\
\text { pseudotuberculosis. }\end{array}$ \\
\hline Limitations: & $\begin{array}{l}\text { It does not detail the populations or how the randomisation was } \\
\text { performed. }\end{array}$ \\
\hline
\end{tabular}

\section{Appraisal, application and reflection}

In the study by Stanford et al. (1998) three experiments were carried out in different periods, with a large population of 3249 lambs of different breeds. Commercial vaccines were used and one that had not been tested previously of whole cell containing the synthetic adjuvant muramyl dipeptide-sn-glyceryldipalmitoyl (WC+MDP-GDP), and both were efficient in provoking immune response.

Panton et al. (1995) conducted an experiment with 450 lambs, where some animals were vaccinated and others were not and some periods were challenged with C. pseudotuberculosis. LeaMaster (1987) also conducted an experiment comparing vaccinated and unvaccinated animals, and one of the vaccinated groups received two doses of vaccine and demonstrated that vaccinated animals had fewer internal lesions and abscesses, especially those who received two doses of vaccine.

Eggleton (1991) conducted two studies, which found similar efficacy of all vaccines used, indicating the overall efficacy of vaccines in the control of CLA infection. Menzies et al. (1991) found a significant difference in the proportion of vaccinated sheep that developed CLA compared to control (unvaccinated) sheep at each 
time interval, except less than 6 months after initial vaccination

Izgür et al. (2010) and Ghani et al. (2016) found encouraging results comparing vaccinated and unvaccinated animals, where again it was found that vaccinated animals are at a lower risk of contracting clinical disease. Eshra et al. (2018) demonstrated that the inactivated C. pseudotuberculosis vaccine prepared with adjuvant with the ISA 206 montanide oil associated with the BCG vaccine induced cellular and humoral immunity and could be used for prevention and control of CLA in sheep.

Syame et al. (2018) verified the efficacy of several vaccines including those combined and concluded that the PLD toxoid vaccine alone was more efficient and provided immune response in animals against CLA, causing a higher rate of stimulation, expressing a greater proliferative response than the other vaccines.

In conclusion, all studies are primary and performed through randomisation (having as a limitation that is not explained how the randomisations was performed). Nevertheless there is evidence that the vaccination is an efficient prophylactic measure against caseous lymphadenitis for sheep flocks.

\section{Methodology Section}

\section{Search}

Databases searched and dates CAB Abstracts on the OVID Platform 1973-2018 Week 51

covered: PubMed accessed via the NCBI website 1910 - December 2018

Search strategy: CAB Abstracts

1. (sheep or sheeps or ovine or ovines or ovis or lamb or lambs or ewe or ewes or ram or rams or dam or dams).mp. or exp sheep/ or exp ewe/ or exp dams/or exp rams/ or exp ovis/

2. (caseous lymphadenitis or CLA).mp. or exp caseous lymphadenitis/

3. (vaccine or vaccines or vaccinate or vaccinated or vaccination or immunize or immunized or immunization or immunise or immunised or immunisation or inoculate or inoculated or inoculation).mp. or exp vaccines/ or exp immunization/ or exp inoculation

4. 1 and 2 and 3

\section{PubMed}

1. sheep or sheeps or ovine or ovines or ovis or lamb or lambs or ewe or eves or ram or rams or dam or dams

2. caseous lymphadenitis or CLA

3. vaccine or vaccines or vaccinate or vaccinated or vaccination or immunize or immunized or immunization or immunise or immunized or immunisation or inoculate or inoculated or inoculation

4. 1 and 2 and 3

Dates searches performed: 9 January 2019

Exclusion / Inclusion Criteria 
Exclusion: Did not answer PICO question, non-primary research, not English or Spanish or Portuguese language, study in other species and was not possible to access the study.

Inclusion: Answer PICO question, primary research, English or Spanish or Portuguese language, study in lambs and was possible to access the study.

Please add/delete rows as necessary

\begin{tabular}{|c|c|c|c|c|c|c|c|}
\hline \multicolumn{8}{|c|}{ Search Outcome } \\
\hline Database & $\begin{array}{c}\text { Number } \\
\text { of } \\
\text { results }\end{array}$ & $\begin{array}{l}\text { Excluded } \\
\quad- \\
\text { did not } \\
\text { answer } \\
\text { PICO } \\
\text { question }\end{array}$ & $\begin{array}{l}\text { Excluded } \\
\text { - non- } \\
\text { primary } \\
\text { research }\end{array}$ & $\begin{array}{c}\text { Excluded - } \\
\text { not English or } \\
\text { Spanish or } \\
\text { Portuguese } \\
\text { language }\end{array}$ & $\begin{array}{l}\text { Excluded - } \\
\text { study in other } \\
\text { species }\end{array}$ & $\begin{array}{l}\text { Excluded - It } \\
\text { was not } \\
\text { possible to } \\
\text { access the } \\
\text { study }\end{array}$ & $\begin{array}{c}\text { Total } \\
\text { relevant } \\
\text { papers }\end{array}$ \\
\hline $\begin{array}{l}\mathrm{CAB} \\
\text { Abstracts }\end{array}$ & 160 & 108 & 27 & 3 & 9 & 4 & 9 \\
\hline PubMed & 78 & 61 & 3 & 0 & 3 & 0 & 11 \\
\hline \multicolumn{7}{|c|}{ Total relevant papers when duplicates removed } & 10 \\
\hline
\end{tabular}

\section{CONFLICT OF INTEREST}

The author declares no conflict of interest.

\section{REFERENCES}

1. Eggleton, D.G., Doidge, C.V., Middleton, H.D., Minty, D.W. 1991.Immunisation against ovine caseous lymphadenitis: efficacy of monocomponent Corynebacterium pseudotuberculosis toxoid vaccine and combined clostridial-corynebacterial vaccines.Australian Veterinary Journal. 68(10):320-321.

2. Eggleton, D.G., Middleton, H.D., Doidge, C.V., Minty, D.W. 1991. Immunisation against ovine caseous lymphadenitis: comparison of Corynebacterium pseudotuberculosis vaccines with and without bacterial cells. Australian Veterinary Journal 68(10):317-319.

3. Eshra, M.A., Mahmoud, A.K.A., Elshemey, T.M., Abdurrahman, A.H. Abbas, O.M. Alexandria. 2018. A trial for vaccination of sheep against Caseous lymphadentitis using oil adjuvent bacterin enhance by Bacillus Calmette-Guerin vaccine. Journal of Veterinary Sciences; 2018. 57(1):140-147. 
DOI: $\underline{5455 / a j v s .283455}$

4. Ghani, T.Y., Habasha, F.G. 2016. Caseous lymphadenitis in Iraqi sheep and assessment of vaccination with commercial vaccine. Basrah Journal of Veterinary Research 2016. 15(3):532-541.

5. Izgur, M., Akan, M., Ilhan, Z., Yazcoglu, N.. Studies on vaccine development for ovine caseous lymphadenitis. Universitesi Veteriner Fakultesi Dergisi 57(3):161-165.

6. LeaMaster, B.R., Shen, D.T., Gorham, J.R., Leathers, C.W., Wells, H.D. 1987. Efficacy of Corynebacterium pseudotuberculosis bacterin for the immunologic protection of sheep against development of caseous lymphadenitis.American Journal of Veterinary Research 48(5):869-872.

7. Menzies, P.I., Muckle, C.A., Brogden, K.A., Robinson, L. 1991. A field trial to evaluate a whole cell vaccine for the prevention of caseous lymphadenitis in sheep and goat flocks. Canadian Journal of Veterinary Research; 1991. 55(4):362-366.

8. Paton, M.W., Sutherland, S.S., Rose, I.R., Hart, R.A., Mercy, A.R., Ellis, T.M. 1995. The spread of Corynebacterium pseudotuberculosis infection to unvaccinated and vaccinated sheep. Australian Veterinary Journal 72(7):266-269.

9. Sohier, S.M., Abuelnaga, A.S.M., Ibrahim, E.S., Hakim, A.S. 2018. Evaluation of specific and non-specific immune response of four vaccines for caseous lymphadenitis in sheep challenged. Veterinary World; 2018. 11(9):1272-1276. DOI: 14202/vetworld.2018.1272-1276

10. Stanford, K. Brogden, K.A., McClelland, L.A., Kozub, G.C., Audibert, F. 1998. The incidence of caseous lymphadenitis in Alberta sheep and assessment of impact by vaccination with commercial and experimental vaccines. Canadian Journal of Veterinary Research 62(1):38-43. 


\section{EVIIDENape \\ brought to you by \\ RCVS KNOWLEDGE}

\section{Intellectual Property Rights}

Authors of Knowledge Summaries submitted to RCVS Knowledge for publication will retain copyright in their work, and will be required to grant RCVS Knowledge a non-exclusive license of the rights of copyright in the materials including but not limited to the right to publish, re-

publish, transmit, sell, distribute and otherwise use the materials in all languages and all media throughout the world, and to license or permit others to do so.

\section{Disclaimer}

Knowledge Summaries are a peer-reviewed article type which aims to answer a clinical question based on the best available current evidence. It does not override the responsibility

of the practitioner. Informed decisions should be made by considering such factors as individual clinical expertise and judgement along with patient's circumstances and owners' values. Knowledge Summaries are a resource to help inform and any opinions expressed within the Knowledge Summaries are the author's own and do not necessarily reflect the view of the RCVS Knowledge. Authors are responsible for the accuracy of the content. While the

Editor and Publisher believe that all content herein are in accord with current recommendations and practice at the time of publication, they accept no legal responsibility

for any errors or omissions, and make no warranty, express or implied, with respect to material contained within.

For further information please refer to our Terms of Use.

RCVS Knowledge is the independent charity associated with the Royal College of Veterinary Surgeons (RCVS). Our ambition is to become a global intermediary for evidence based veterinary knowledge by providing access to information that is of immediate value to practicing veterinary professionals and directly contributes to evidence based clinical decision-making.

\section{https://www.veterinaryevidence.org/}

RCVS Knowledge is a registered Charity No. 230886.

Registered as a Company limited by guarantee in England and Wales No. 598443. 
Registered Office: Belgravia House, 62-64 Horseferry Road, London SW1P 2AF

$$
\text { (@) } \underset{0}{(1)}
$$

This work is licensed under a Creative Commons Attribution 4.0 International License 